УДК 378:811.111

\title{
ВИКОРИСТАННЯ ПЛАТФОРМИ МYЕNGLISHLAВ У НАВЧАННІ МАЙБУТНІХ ЮРИСТІВ АНГЛІЙСЬКОЇ МОВИ
}

\author{
Мись T.I. \\ tatyanamys@ukr.net \\ Київський наиіональний економічний університет імені Вадима Гетьмана \\ Дата надходження 21.03.19. Рекомендовано до друку 18.04.2019.
}

\begin{abstract}
Анотація. У статті розглядається впровадження і переваги використання на практиці викладання англійської мови в системі дистанційної освіти студентів юридичних спеціальностей на базі навчального середовища Myenglishlab.
\end{abstract}

Ключові слова: платформа MyEnglishLab, навчальне середовище, юридичні спеціальності, ресурс, англійська мова.

Мысь Т. И. Киевский национальный экономический университет имени Вадима Гетьмана Использование платформы MyEnglishLab в процессе обучения будущих юристов английскому языку

Аннотация. В статье рассматривается внедрение и преимущества использования на практике преподавания английского языка в системе дистанционного образования студентов юридических специальностей на базе учебной среды Myenglishlab.

Ключевые слова: платформа MyEnglishLab, учебная среда, юридические специальности, ресурс, английский язык.

Mys T. Kyiv National Economic University named after Vadym Hetman

The usage of MyEnglishLab platform in the process of teaching English for future lawyers

Abstract. Introduction. The article discusses the introduction and advantages of using in the practice of teaching English in the system of distance education of law students on the basis of the MyEnglishLab learning environment. Purpose. To identify the opportunities, advantages and prospects of using the MyEnglishLab e-learning platform for learning a foreign language in the process of future lawyers training. Methods. During the study of such form of education, which is in the process of formation and development, the descriptive method, the method of analysis and synthesis were used. We also relied on the research of different scholars. Results. This study shows, that the main emphasis is placed on the following types of activities: the ability to writing, reading and understanding of legal texts, terminology, free expression of opinion, analysis of reading, understanding of audio and video materials. A comprehensive approach, enables not only to increase the volume of studying the program, but also to make the learning process more interesting and diversified. The combination of full-time and distance learning with the use of modern Internet technologies has many advantages, both for the student and for the teacher, which can significantly improve the quality of foreign language learning. The platform changes the view on traditional teaching of a foreign language, bringing it to a new, European level. Conclusion. We can conclude that using of MyEnglishLab platform for teaching a foreign language, gives teachers a modern, powerful resource, through which she or he can not only fully present the new material, but also control, evaluate the performance and success of the students. This platform provides many tools for application, and this type of learning is called complex, effective, and stimulating. There are not many scientific developments on this issue, so theoretical and practical work in this area is extremely relevant.

Key words: MyEnglishLab platform, learning environment, legal professions, resource, English language. 
Постановка проблеми. На сьогоденному етапі розвитку людства сучасні інформаційні технології є невід'ємною частиною: вони не тільки покращують життя, а й позитивно впливають на сферу освітньої діяльності. Наразі модернізація вітчизняної системи освіти дедалі частіше пов’язується з розвитком дистанційного навчання як одним з істотних факторів підвищення конкурентоспроможності на ринку освітніх послуг. Як новий сучасний ресурс ця форма навчання широко застосовується в країнах Західної Свропи, США й інших розвинутих країнах (Шуневич, 2008; Simpson, 2012). Це система комплексного навчання студента як ефективного поєднання традиційної форми навчання з викладачем і навчання студента он-лайн. Це своєрідна віртуальна лабораторія, яка об'єднує викладачів і студентів, значно розширюючи можливості викладання англійської мови із залученням сучасних технологій, зокрема інформаційно-комунікаційних.

Аналіз останніх досліджень і публікацій. Дистанційна форма навчання перебуває в процесі становлення й розвитку, але цією проблемою, а саме використанням новітніх інформаційних технологій в освітньому процесі закладів вищої освіти (3ВО) займались такі науковці: Дж. Андервуд, О. Андрєєв, С. Бєлова, А. Бернадський, В. Беспалько, І. Булах, В. Романюк, В. Тихомиров, В. Ящур, Т. Кашицин. Розглядом такого питання, як використання елементів дистанційного навчання студентів 3ВО, займались С. Смірнова-Трибульська, M. Прадівляний, Т. Коваль. На платформі MyEnglishLab навчаються студенти таких університетів, як Київський національний університет імені Вадима Гетьмана, Київський національний університет імені Тараса Шевченка, Національний університет “Львівська політехніка", Київський національний торговельно-економічний університет, Харківський національний університет імені В.Н. Каразіна, Національний технічний університет "Харківський політехнічний інститут”, Таврійський Національний Університет імені В. І. Вернадського, Міжнародний Інститут Менеджменту МІМ-Київ, Українсько-американський університет Конкордія, Сумський державний університет.

Мета статті полягає у визначенні можливостей, переваг і перспектив використання електронно-навчальної платформи MyEnglishLab для вивчення іноземної мови в процесі підготовки майбутніх юристів.

Основні результати дослідження. Уявити освітній процес у ЗВО без англійської мови у сучасному глобальному світі практично неможливо. Англійська мова є мовою міжнародного спілкування, яка є невіддільним елементом для кожного професіонала. Майбутні фахівці, зокрема студенти юридичних спеціальностей, мають володіти англійською мовою як на повсякденному, так і на професійно орієнтованому рівні. За міжнародними вимогами рівень їх володіння англійською мовою не може бути нижчим, ніж В2, що вказано в “Загальноєвропейській компетенції володіння іноземною мовою” (Council of Europe). На жаль, цим рівнем володіє не кожен студент. I забезпечити досягнення цього рівня без новітніх Інтернет-технологій неможливо. Комплексний підхід, а саме задіяння комп'ютерної техніки й багатоманітних програмних забезпечень дають змогу не тільки збільшити обсяг виучуваної навчальної програми, а й зробити освітній процес цікавішим, різноманітним і поглибленим. Поєднання очної й заочної форм навчання з використанням сучасних Інтернет-технологій має безліч переваг як для студента, так і для викладача іноземної мови, що дає змогу значно підвищити якість іншомовної освіти.

Починаючи з XII століття, засадами вивчення англійської мови є дієвість і практичність. 3 урахуванням поставленої мети - оволодіння студентською молоддю іноземною мовою на високому рівні - вітчизняні ЗВО активно впроваджують систему іiі дистанційного навчання. Характерними рисами цього типу навчання концепція дистанційної освіти в Україні виокремлює гнучкість, модульність, паралельність, можливість залучити одночасно велику аудиторію, економічність, технологічність, соціальну рівність, інтернаціональність, отримання викладачем нової ролі в процесі навчання, позитивний вплив на студента, якість (“Концепція розвитку дистанційної освіти ...”). 
Мета навчальної дисципліни "Іноземна мова" полягає у формуванні у студентів здатності до міжкультурного спілкування, яке щодо майбутніх юристів має професійне спрямування та реаізується в процесі формування міжкультурної комунікативної компетентності. Остання, в свою чергу, визначається як такий рівень володіння мовленнєвими, мовними, соціокультурними й професійно предметними знаннями, навичками й уміннями рідною та іноземною мовами, який дає змогу комунікативно прийнятно здійснювати міжкультурне спілкування (Киктева, 2009). Водночас завдяки посиленню інтеграційних процесів України до європейських і світових структур дедалі більшої актуальності набуває усне мовлення англійською мовою, адже в перспективі майбутні юристи можуть проходити стажування в інших країнах, зокрема англомовних, де їм доведеться спілкуватися в усній формі. Навчання на платформі MyEnglishLab уможливлює ефективне вирішення цієї проблеми шляхом постійного й достатньо динамічного спілкування студентів між собою та 3 носіями мови в освітньому процесі, причому ініціювання цього спілкування можливе 3 боку будь-якого 3 перелічених суб'єктів освітнього процесу.

Викладач іноземної мови отримує нову роль, втілюючи концепцію соціального конструктивізму, згідно з якою він відходить від “головної ролі” і перевтілюється в керівника, який забезпечує студентів можливістю перевірити правильність свого розуміння матеріалу в конктерний момент навчання іноземної мови. Студент формує нові знання шляхом активного залучення до навчання, задля отримання нових знань викладач забезпечує студента необхідними ресурсами, допомагає асиміляції старих і нових знань. Викладач створює середовище, в якому студенти можуть вільно ставити запитання. “Конструктивізація” навчання досягається шляхом створення ситуацій, максимально наближених до життя (Jennings, Surgenor, \& McMahon, 2013). Тому для втілення концепції соціального конструктивізму якнайкраще підходить платформа MyEnglishLab, яка надає нові можливості вивчення англійської у форматі Blended Learning. Головним чинником навчання на платформі MyEnglishLab $€$ інтерактивна діяльність викладачів зі студентами з використанням усіх можливостей платформи.

Платформа MyEnglishLab надає студенту такі можливості:

1. Виконувати в режимі он-лайн велику кількість завдань, спеціально розроблених до навчального курсу, з яким він працює (див. рис 1-3).

2. Мати у своєму розпорядженні бібліотеку навчальних матеріалів й інтерактивних вправ.

3. Використовувати відео- й аудіоматеріали для самостійного опрацювання.

4. Отримувати докладні звіти після автоматичної перевірки виконаних завдань, що суттєво допомагає фіксувати, аналізувати й виправляти свої помилки.

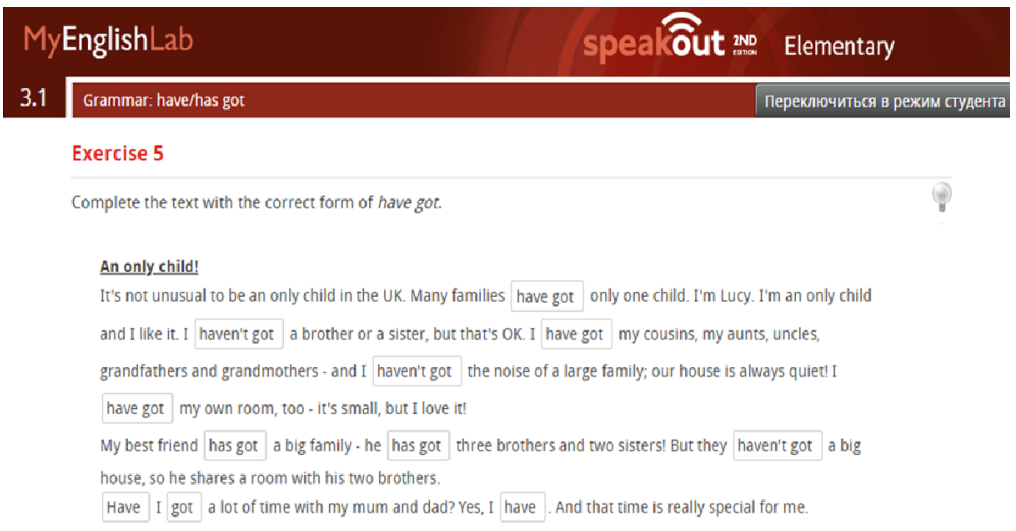

Рис 1. Приклад граматичних вправ 


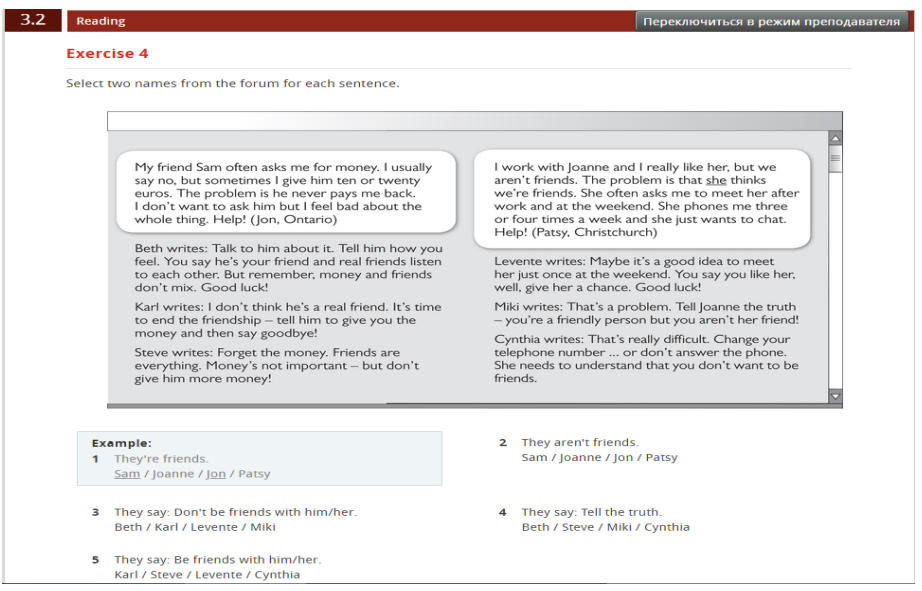

Рис. 2. Приклад завдань для перевірки розуміння прочитаного

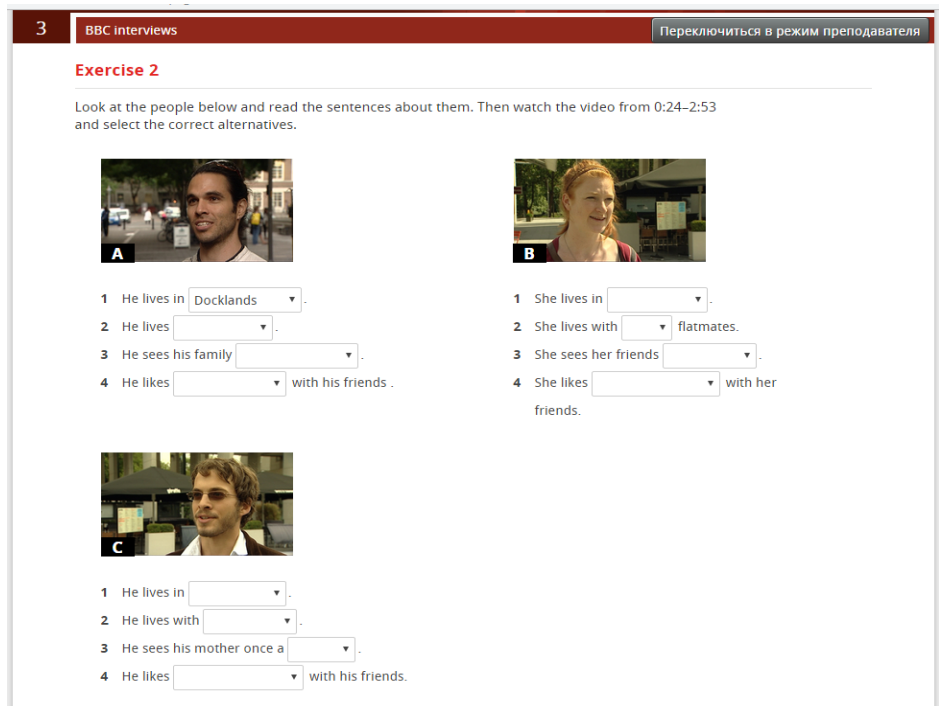

Рис 3. Приклад вправ для навчання аудіювання

Натомість викладачеві англійської мови надаються такі можливості:

1. Вести моніторинг успішності академічної групи в цілому й конкретних студентів, отримуючи перевірені програмою завдання, а також відстежувати перебіг навчання, користуючись он-лайн журналом, також заповнюваним програмою MyEnglishLab.

2. Спілкуватися зі студентами в режимі реального часу, встановлюючи терміни виконання завдань (з функцією нагадування), обираючи завдання для всієї групи чи для окремого студента індивідуально й аналізуючи результати автоматично перевірених завдань.

3. Контролювати самостійну роботу студентів, бачити об'єктивний стан успішності засвоєння виучуваного матеріалу (див. рис. 4).

4. Самостійно налаштовувати програму для своїх потреб. 


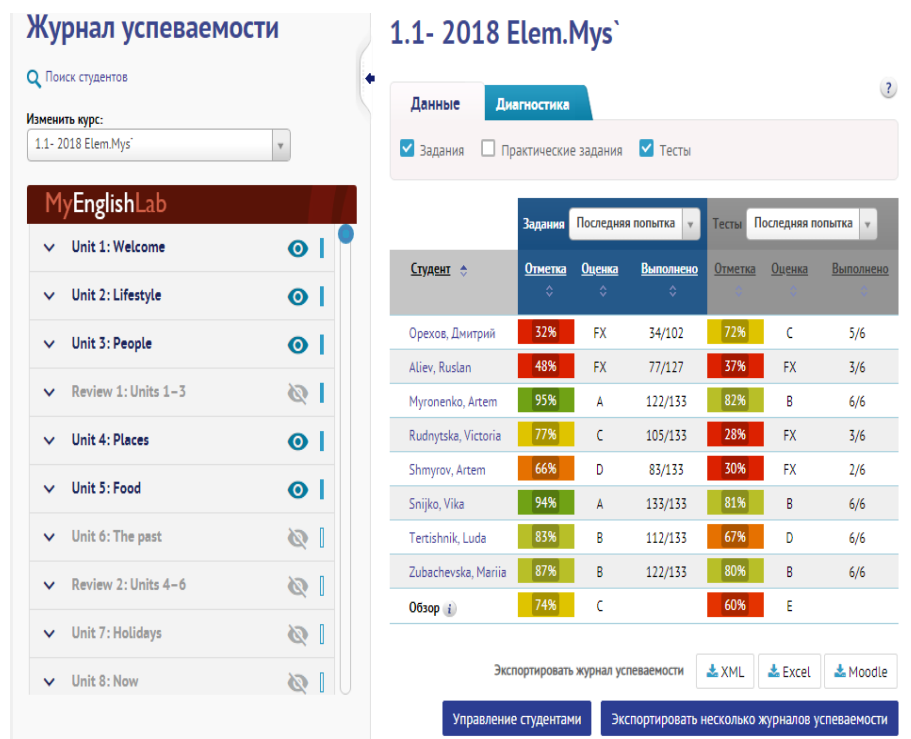

Рис 4. Платформа із зазначеною успішністю студентів

На практиці користуючись платформою MyEnglishLab, творчі викладачі знаходять дедалі більше переваг цієї комунікативної платформи в багатоканальному середовищі. Завдяки великій кількості ресурсів вона уможливлює організацію повноцінного освітнього процесу, забезпечуючи індивідуальний підхід до кожного студента, який може працювати 3 нею в будь-який час і в будь-якому місці, де $є$ доступ до Інтернет-мережі. Для студентів юридичних спеціальностей акцентуються такі види англомовної мовленнєвої діяльності, як письмо, читання й розуміння юридичних текстів, термінології, вільного висловлювання своєї думки, аналіз прочитаного, розуміння аудіо- й відеоматеріалів. Платформа змінює погляд на традиційне навчання іноземної мови, підносячи його на новий, європейський рівень. Різноманітний ресурс електронної складової змішаного курсу відкриває нові можливості презентації навчального матеріалу, дає студентам змогу самостійно визначати індивідуальну траєкторію учіння.

Виокремлюється низка переваг цієї платформиі:

о можливість урізноманітнити освітній процес;

о багаторазове повторення введених лексичних одиниць і граматичних структур;

о отримання якісного зворотного зв'язку;

о формування у студентів навчальних умінь планувати й організовувати учіння, орієнтуючись на поставлені цілі й очікувані результати;

о підвищення мотивації студентів до вивчення англійської мови;

о економія аудиторного часу через винесення певних видів завдань на самостійне опрацювання;

о можливість ураховувати індивідуальні особливості студентів щодо сприйняття інформації;

о підвищення ефективності комунікації між студентом і викладачем, що дає викладачу змогу координувати й моделювати учіння студентів.

Водночас платформі властива низка недоліків:

о побоювання використання нових технологій або їх відсутність у викладачів і студентів;

о платформа не $\epsilon$ стимулювальним фактором навчання іноземної мови чи ії оволодіння, якщо студент не має бажання досягати успіху у вивченні іноземної мови, то виконання завдань стає формальним, звичайним списуванням із залученням новітніх технічних досягнень. 
Висновки і перспективи подальших розвідок. Таким чином, використовуючи платформу MyEnglishLab для навчання іноземної мови, викладач отримує сучасний потужний ресурс, завдяки якому він не тільки всебічно презентує новий матеріал, а й контролює й оцінює учіння й успішність студентів. Платформа має багато інструментів для застосування, тому навчання на ii основі стає комплексним, дієвим, стимулювальним. Наразі доволі складно зацікавити студента, особливо того, який “все бачив”. Платформа усуває ці моменти, тому що вона йде в ногу з часом, розвитком, а також порушує не тільки цікаві теми, а й морально-орієнтовані, які стимулюють критичне мислення у студентів і мотивують до пізнання невідомого раніше, пошуку нової інформації, до руху, розвитку. Тому для отримання найкращого результату викладачам і студентам необхідно мати бажання навчитися працювати в такому навчальному середовищі, не боятися змінювати погляд на сучасний процес викладання та вивчення іноземних мов. Наукових доробків із зазначеного питання не так багато, тому теоретична і практична робота в цьому напрямку надзвичайно актуальна, що і становить перспективу подальших досліджень в цій сфері.

\section{ЛІТЕРАТУРА}

Василевич, Ю. В., \& Каліцева, О. В. (2010). Дистанційна освіта студентів-юристів: сучасний стан, проблеми, перспективи. В Спецпроект: анализ научных исследований. Тези доповідей V Міжнародної науково-практичної Інтернет-конференції, 17-18 червня 2010 р. Взято 3 http://www.confcontact.com/2010spec_tezi/pe_vasilev.php

Дишлева, Ю. В. (2008). Роль та місце сучасних методик у вивченні англійської мови в курсі дистанційного навчання. Викладання мов у вищих навчальних закладах освіти на сучасному етапі. Міжпредметні зв'язки. Наукові дослідження. Досвід. Почуки, 13, 35-41.

Киктева, К. С. (2009). Методика формирования иноязычных межкультурных учений письменной речи юристов (неязыковой вуз, английский язык) (Автореферат кандидатской диссертации). Московский государственный университет имени М.В. Ломоносова, Москва, Российская Федерация.

Кониеепиія розвитку дистаниійної освіти в Україні. Взято з http://www.osvita.org.ua/distance/ pravo/00.html

Шуневич, Б. І. (2008). Розвиток дистаниійного навчання у вищій школі країн Свропи та Північної Америки (Автореферат докторської дисертації). Інститут вищої освіти АПН України, Київ, Україна.

Council of Europe. Common European Framework of Reference for Languages: Learning, Teaching, Assessment (CEFR). Retrieved from https://rm.coe.int/16802fc1bf

Jennings, D., Surgenor, P., \& McMahon, T. (2013). Education Theory : Constructivism and Social Constructivism in the Classroom. UCD CTAG. Ucdoer.ie. N.p., 2013. Web. 6 May 2016. Retrieved from http://www.ucdoer.ie/index.php/Education_Theory/Constructivism_and_Social_ Constructivism in the Classroom

Kruse, K. The Benefits and Drawbacks of e-Learning. Retrieved from http://www.corebiztechnology.com/ software_article_elearning_d.htm

MyEnglishLab - an online component to complement your favourite English language course from Pearson. Retrieved from https://www.pearson.com/english/myenglishlab.html

Richards, J. C. (2008). Approaches and Methods in Language Teaching. Cambridge Univ. Press. Retrieved from http://www.espacomarciocosta.com/pdf/ingles/questoes-teoricas-e-metodologicas/ approaches-and-methods-in-language-teaching-jack-c-richards-and-theodore-s-rodgers.pdf

Simpson, O. (2012). Supporting Students for Success in Online and Distance Education. New York and London: Routledge. 


\section{REFERENCES}

Vasylevych, Yu. V., \& Kalitseva, O. V. (2010). Dystantsijna osvita studentiv-iurystiv: suchasnyj stan, problemy, perspektyvy. V Spetsproekt: analyz nauchnykh yssledovanyj. Tezy dopovidej V Mizhnarodnoi naukovo-praktychnoi Internet-konferentsii, 17-18 chervnia 2010 r. Vziato z http://www.confcontact. com/2010spec_tezi/pe_vasilev.php

Dyshleva, Yu. V. (2008). Rol' ta mistse suchasnykh metodyk u vyvchenni anhlijs'koi movy v kursi dystantsijnoho navchannia. Vykladannia mov u vyschykh navchal'nykh zakladakh osvity na suchasnomu etapi. Mizhpredmetni zv'iazky. Naukovi doslidzhennia. Dosvid. Poshuky, 13, 35-41.

Kykteva, K. S. (2009). Metodyka formyrovanyia ynoiazychnykh mezhkul'turnykh uchenyj pys'mennoj rechy iurystov (neiazykovoj vuz, anhlyjskyj iazyk) (Avtoreferat kandydatskoj dyssertatsyy). Moskovskyj hosudarstvennyj unyversytet ymeny M.V. Lomonosova, Moskva, Rossyjskaia Federatsyia.

Kontseptsiia rozvytku dystantsijnoi osvity v Ukraini. Vziato z http://www.osvita.org.ua/distance/ pravo/00.html

Shunevych, B. I. (2008). Rozvytok dystantsijnoho navchannia u vyschij shkoli krain Yevropy ta Pivnichnoi Ameryky (Avtoreferat doktors'koi dysertatsii). Instytut vyschoi osvity APN Ukrainy, Kyiv, Ukraina.

Council of Europe. Common European Framework of Reference for Languages: Learning, Teaching, Assessment (CEFR). Retrieved from https://rm.coe.int $/ 16802 \mathrm{fclbf}$

Jennings, D., Surgenor, P., \& McMahon, T. (2013). Education Theory : Constructivism and Social Constructivism in the Classroom. UCD CTAG. Ucdoer.ie. N.p., 2013. Web. 6 May 2016. Retrieved from http://www.ucdoer.ie/index.php/Education_Theory/Constructivism_and_Social_ Constructivism in the Classroom

Kruse, K. The Benefits and Drawbacks of e-Learning. Retrieved from http://www.corebiztechnology.com/ software_article_elearning_d.htm

MyEnglishLab - an online component to complement your favourite English language course from Pearson. Retrieved from https://www.pearson.com/english/myenglishlab.html

Richards, J. C. (2008). Approaches and Methods in Language Teaching. Cambridge Univ. Press. Retrieved from http://www.espacomarciocosta.com/pdf/ingles/questoes-teoricas-e-metodologicas/ approaches-and-methods-in-language-teaching-jack-c-richards-and-theodore-s-rodgers.pdf

Simpson, O. (2012). Supporting Students for Success in Online and Distance Education. New York and London: Routledge. 